\title{
ドイツにおけるペッテンコーファーとコッホの有意義な生誕祝賀式典
}

\author{
松下 敏夫 ${ }^{1}$ (紹介者)，ベアーテ・ヴォンデ ${ }^{2}$ (原著者) \\ ${ }^{1}$ 鹿児島大学 \\ 2 フンボルト大学ベルリン森鷗外記念館
}

\section{Significant Birthdays of Pettenkofer and Koch Celebrated in Germany}

\author{
Toshio MATSUSHITA ${ }^{1}$ (introducer) and Beate $\mathrm{WONDE}^{2}$ (author) \\ ${ }^{1}$ Kagoshima University \\ ${ }^{2}$ Mori Ôgai Memorial Center, Humboldt University of Berlin
}

\begin{abstract}
この資料は，2018 年にドイッで行われた Max von Pettenkofer と Robert Koch の生誕記念祝賀事業に関 して,フンボルト大学ベルリン森鷗外記念館の Beate Wonde 氏が, 私信として提供してくれた情報である。 本学会会員にも興味ある有益な情報と考光, 本人の承諾を得て, 原文の一部を補経して資料として紹介 する次第である。

な拈，原著者のベアーテ・ヴォンデ氏の多彩な日独文化交流活動や，フンボルト大学ベルリン森鷗外 記念館に関しては，ホームページを参照されたい。
\end{abstract}

松下敏夫（鹿児島大学）

\section{ドイツにおけるペッテンコーファーとコッホの 有意義な生誕祝賀式典

$$
\text { ベアーテ・ヴォンデ }
$$ \\ （フンボルト大学ベルリン森鷗外記念館）}

2018 年も終わりに差しかかった頃, ドイッでは森鷗 外の師であり医学史に拈ける功労者二人を偲ぶ会議が あった。12月 3 日はマックス・フォン・ペッテンコー ファー（Max von Pettenkofer, 1818-1901）生誕 200 年の 日であり，同 11 日はロベルト・コッホ（Robert Koch, 1843-1910）生誕 175 年の日であった。立て続けに催し が企画されたことで，ライバル関係にあった二人の 25 歳といら年齢差が特別際立った。この二人は全く違ら性 格であっただけでなく，違ら世代に属していたのだ。

ペッテンコーファーの祝賀式典は，12月 3 日にドナ ウモースのリヒテンハイムにある彼の生家横に建つ胸像 に献花することで幕を開けた。この式典には, 市長のほ か郡知事や住民らも参加した。ペッテンコーファーの出

受付 2019 年 1 月 29 日, 受理 2019 年 1 月 30 日

Reprint requests to: Toshio MATSUSHITA

Kagoshima University, 2-16-8 Takeoka, Kagoshima 890-0031, Japan

TEL \& FAX: +81(99)281-6435

E-mail: m-toshio33@sings.jp
身地は, インゴルシュタットやニュルンベルクの近くに 位置するノイブルク・アン・デア・ドナウの傍にある。 この辺りは瘦せた平地で，沼地の水を抜いて開拓された 土地だ。彼の生家はもら残っていないのだが, 数年前に 復元され，碑文が添えられている。

当日午後には, ノイブルク・アン・デア・ドナウの 職業学校がペッテンコーファー学校と名付けられた名 前の授与式が行われた。同校の生徒はこの日のために 「ペッテンコーファー石鹸」を作って扣り, これから 1 年 間ペッテンコーファーについてさらに学ぶ予定だ。

授与式に引き続いて，医学史家のヴォルフガング・ ロッハー教授が講演を行った。教授は，今年 7 月にペッ テンコーファーの伝記『Max von Pettenkofer Pionier der wissenschaftlichen Hygiene（マックス・フォン・ペッテ ンコーファー：衛生学の先駆者)』(ドイッ語) を出版し ている。

な拈，カール・ヴィーニンガー氏によるペッテンコッ ファーの伝記は，1987 年に出版された。植木絈子氏に よって 2007 年に日本語に翻訳され，『知られざる科学者 ペッテンコーフェルー環境医学の創始者一』といら邦題 で知られている。そこには森本兼鼌氏と松下敏夫氏によ る序文が添えられている。

夕方には, ベルリン森鷗外記念館のキュレーターであ る私・ベアーテ・ヴォンデが，「モース・ハウス HAUS 
im MOOS」に扔いて「ペッテンコーファーと日本の弟 子たち」といら題で講演し, 主に緒方正規, 中濱東一郎, 小池正直，坪井次郎，後藤新平に関して述べた。

同月 6 日から 8 日にかけてはミュンヘンに打いても祝

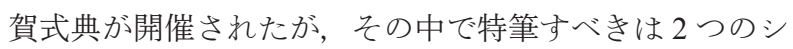
ンポジゥムだろう。ひとつは国際的な学術シンポジゥム 「感染生物学一感染症学 2018一マックス・フォン・ペッ テンコーファー生誕 200 年を記念して」で, もらひとつ は「マックス・フォン・ペッテンコーファーと 21 世紀 に拈ける彼の意義」だ。そこでは, ペッテンコーファー 賞の授与式も行われた。同賞は 2017 年に創設され, バ イエルンの大学, 専門大学で提出された衛生学と医学微 生物学に関する優れたディプローム, 学士, 修士, 博士 論文に対して授与されて扮り，賞金は5,000 ユーロであ る。

また，ミュンヘンの市立博物館では，新な特別展「チ フスの街ミュンヘン:ペッテンューファーとミュンヘン」 が開かれている。

ベルリンでは, ロベルト・コッホの 175 回目の誕生日 を記念した式典が彼の名を冠した研究所の図書閲覧室で 催された。ここは 2 年前にロベルト・コッホ研究所の設 立 125 周年を祝して連続特別企画「ロベルト・コッホ・
サロン」が行われた場所で，その時は，各々の登壇者た ちが赤いソファに座り座談会を行った。

今回の式典では, 感染症部門部長のマルティン・ミー ルケ教授が具体例を示しながらコッホの功績を称えた。 続いて, 同研究所所長のローター・H・ヴィーラー教授が, コッホの會孫にあたるヴォルフガング・プフール氏にイ ンタビューを行った。プフール氏の祖母ゲルトゥルート は, コッホの唯一の子供である。インタビュ一の中で, コッホ家は，ロベルトが少年時代を過ごしたクラウス タールにある家を買い戻して復元したことが述べられ た。同式典はロビーと展示室でのささやかなパーティー で締めくくられたが，お土産として小さなテレビ型ミニ の帒眼鏡が配られた。ボタンを押すといくつかのコッ ホの写真を見る事が出来る仕掛けだ。

今日, マックス・フォン・ペッテンコーファー研究所 とロベルト・コッホ研究所は協㗢関係にある。ロバート ・コッホ基金による優れた研究を発表した後進者に授与 するポスト・ドクター賞の 2018 年受賞者は, ミュンへ ン大学マックス・フォン・ペッテンコーファー研究所に 在籍するウイルス学者マクシミリアン・ミュンヒホフ博 土で, 受賞の研究テーマはHIV 感染の解析であった。 